\title{
Populist argumentation in foreign policy: the case of Hungary under Viktor Orbán, 2010-2020
}

\author{
Péter Visnovitz ${ }^{1}$ - Erin Kristin Jenne ${ }^{1}$
}

Accepted: 30 August 2021 / Published online: 14 September 2021

(c) The Author(s), under exclusive licence to Springer Nature Limited 2021

\begin{abstract}
There is a general scholarly consensus that populist governments undermine liberal democracy at home, but less agreement over how they behave abroad. While many scholars still subscribe to the view that populism has no consistent impact on foreign policy, we argue that populist leaders engage in a characteristic set of behaviors calculated to elevate the state's status on the international stage. However, the mechanism by which populist elite-versus people rhetoric translates into concrete foreign policy action remains underspecified. To address this gap, we develop a model showing how populism serves as a political argument to enable status elevation on the international stage. To illustrate this mechanism in action, we analyze the foreign policy rhetoric and behavior of the 2010-2020 Fidesz governments in Hungary, showing how populist argumentation was used to justify revisionist foreign policy through (1) the politicization of diplomatic machinery, (2) confrontation with traditional allies, and (3), the pursuit of more flexible partnerships. In these three respects, we show how populist arguments were used by Orbán to achieve a revolution in Hungarian foreign affairs.
\end{abstract}

Keywords Populism · Foreign policy, · Argument analysis · Hungary · Viktor Orbán

Populist leaders promise to elevate 'the people' by overthrowing 'the establishment'-be it multinational corporations and corrupt elites for left-wing populists like Hugo Chávez, Nicholas Maduro, Evo Morales and Rafael Correa, or global institutions and cultural elites for right-wing populists like Narendra Modi, Jair Bolsonaro, Rodrigo Duterte, Boris Johnson and Donald Trump (Mudde and Kaltwasser 2012; De Cleen and Stavrakakis 2017; Brubaker 2017). But what effect, if any, does this type of firebrand rhetoric have on state foreign policy? Some have argued

Péter Visnovitz

Visnovitz_Peter@phd.ceu.edu

Erin Kristin Jenne

Jennee@ceu.edu

1 Central European University, Vienna, Austria 
that populist governments undermine multilateralism, free trade and even the global liberal order itself (Müller 2016; Balfour et al. 2016). They point out that populist leaders tend to enact foreign policies that are popular with ordinary people such as less investment in global governance and more transactionalism in foreign affairs (Rodrik 2018). In this view, populist rhetoric is a 'costly signal' that populists send to their constituents that they will translate the preferences of ordinary people into policy once they are in office (see Acemoglu et al. 2013). ${ }^{1}$ Since popular preferences run toward protectionism, populist governments can be expected to adopt protectionist trade policies and shrink from global commitments.

Somewhat confoundingly, however, populist leaders have been known to pursue a range of foreign policy agendas-from import-substitution industrialization (ISI) of Argentina's Juan Peron to the neoliberal free trade policies of Peru's Alberto Fujimori, Argentina's Carlos Menem and Brazil's Fernando Collor in the 1990s (Weyland 2001; Roberts 1995). In Europe, too, populist governments have taken different foreign policy stances. The former Nikola Gruevski government in North Macedonia gave full-throated support for the EU, whereas the PiS government in Poland (see Cadier 2021, this volume) and the Orbán government engaged competitively with the EU, while the UK Prime Minister Boris Johnson steered his country out of the EU altogether. Still other populist leaders like India's Narendra Modi have maintained a relatively status quo approach toward global institutions (Plagemann and Destradi 2019).

In light of this diversity, some have argued that populism itself has no consistent effect on foreign policy. Populist elite-versus-people rhetoric is merely 'cheap talk' used to attract voters during elections or divert the public's attention from material grievances (Levitsky and Roberts 2011; Snyder 2000; Roberts 1995). Castigating their opponents as 'evil' or 'corrupt' elites is useful for winning elections, but once in office they usually behave like non-populists (Taggart 2000). Part of the problem is that populism is so ideologically thin-centered, so vague and chameleonic, that it provides little programmatic guidance for policy-making (Weyland 2001; Levitsky and Roberts 2011; Freeden 2017; Mudde 2017). For a fuller account of discrete policy outputs, we must therefore consider the 'thicker ideologies' with which populist rhetoric is articulated in each political context (Verbeek and Zaslove 2017) such as nationalism, authoritarianism and even civilizationalism (Enyedi 2016; Brubaker 2017), an approach we adopt here.

We join the editors of this special issue in arguing that there are commonalities in populist leaders' foreign policies, provided that we move our analytical gaze to a higher level of abstraction. In the lead article of this special issue, Destradi et al. (2021) observe that at the meta-behavioral level, populist leaders can be expected to take a more confrontational foreign policy approach toward their traditional allies; diversify their foreign partnerships; and centralize, personalize and politicize their foreign policy-making. We argue that populism enables these foreign policy practices_-not by translating 'the people's' preferences directly into policy, but by serving as a particular type of political argument that old alliances must be revised and

1 See Drezner( 2017) and Zellman (2020) for similar demarcations.

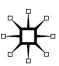


new ones built in order to better represent the people's will internationally. Depicting the populist argument graphically, we show that 'popular sovereignty' serves as an explicit or implicit warrant used to back the government's claims that foreign policy and diplomatic institutions should be politicized in order to confront traditional allies and seek out non-traditional partnerships. Each of these claims derives from the populist argument that foreign elites and international power-holders frustrate the will of the people and/or nation and must therefore be countered and defeated.

We illustrate the function of (ethno-)populist argumentation by Hungarian Prime Minister Viktor Orbán, who at eleven years is one of the longest-ruling populist leaders in the world (Palonen 2018; Enyedi 2016; Hawkins et al. 2019). Orbán has consistently utilized populist rhetoric in his addresses on Hungarian foreign policy (Csehi and Zgut 2020). At the same time, and despite the country's small size, Orbán has undertaken a radical set of reforms on the international stage-assuming a confrontational approach to Hungary's traditional Western partners such as the NATO and EU (Hettyey 2021), strengthening bilateral relations with autocratic countries like Russia and China, and making the Ministry of Foreign Affairs more directly answerable to the prime minister-changes that are directly in line with some of the signature features of populist governments' foreign policies as identified by the other contributors to this issue. Post-2010 Hungary therefore serves as an ideal case for unpacking the causal mechanism between populist rhetoric and foreign policy outputs.

The following section develops our theory that populism serves as a type of political argument that popular sovereignty or 'the will of the people' should be protected against elite machinations; this is sometimes combined with a nationalist sovereignty warrant that 'the nation' should be protected from 'national others.' To deconstruct the connection between rhetoric and policy, we use a modified Toulmin model to graph the (ethno-)populist argumentation that Orbán uses to justify radical foreign policy reform in his speeches and writings. The third section lays out our case study design, and the fourth shows how these arguments were mobilized in pursuit of the three components of foreign policy revisionism. The conclusion offers a brief reflection on the Hungarian case in the context of other cases of populist foreign policy examined in this issue.

\section{Populism as a political argument}

The contemporary study of rhetoric in foreign policy has tended to focus on the emotional content of the speech (pathos) as well as the establishment of the speaker's authority (ethos), for example in securitization theory (Wojczewski 2020). By contrast, there has been less focus on the persuasive function of logic (logos) on foreign policy-making. IR scholars have circled around the topic in a rich body of work subscribing to the linguistic turn in international relations that has examined national roles (Thies 2012), metaphors and analogies (Paris 2002; Khong 1992); norms (Klotz 1995), legitimizing strategies (Goddard and Krebs 2015) and narratives (Subotić 2016; Krebs 2015) in foreign policy, demonstrating through qualitative analysis how speakers make their claims persuasive to their listeners. 
Fig. 1 Populist arguments in foreign policy

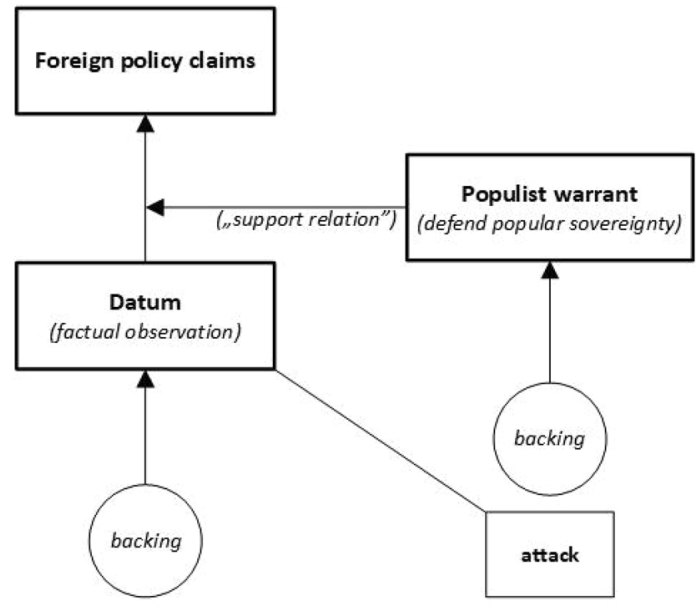

Unlike other legitimizing strategies, arguments have a very structured rhetorical form. They consist of a series of statements (premises) that follow one another logically in support of a conclusion (claim). The speaker makes a specific claim based on a given fact or datum through the aid of a 'warrant' or general principle that is then applied to this specific case. According to Krebs (2015, p. 36), an argument is different from a narrative or story in that it 'seeks to persuade the audience of the correctness of a course of action.' Arguments 'deduce the recommended course of action from general principles, and thus take the form of ' $\mathrm{X}$ fits into category $\mathrm{Y}$, therefore policy A follows.' There are also real (or imaginary) counter-arguments embedded in the process of argumentation. In Arguing and Thinking, Michael Billig observes that arguments are inherently social enterprises that consist not only of arguments, but also rebuttals and counter-rebuttals: 'any individual argument is actually, or potentially, a part of a social argument' with two sides, pro and con (Billig 1989, p. 74; see also Kornprobst 2009 and Cobb and Kuklinski 1997).

Our modified Toulmin model depicts this social process graphically. At the most basic level, arguments consist of (a) a major premise, (b) a minor premise and (c) a conclusion. Figure 1 depicts the logical sequence or 'template' of an argument that is adapted from Homer-Dixon and Karapin (1989, p. 392), based on the work of Toulmin (1958; Toulmin et al. 1984). The model proceeds as follows. First, a data-point is asserted by the speaker, beginning the argument. It may be thought of as a statement of problem. This datum, which might be attacked by opponents to the argument, leads to a conclusion or claim (in our case, about foreign policy[making]) via a warrant, which connects the datum to the claim through a 'support relationship.' The warrant is a covering law or generalizable theory used to link the specific data-point to a conclusion that is sometimes supported by additional backing, which consists of one or more empirical facts used to establish its veracity. In the course of argumentation, an opponent might make an attack on the statement of the problem, supported by additional facts. Effective political argumentation anticipates and answers this rebuttal in the concluding claim. 
We propose that the characteristic feature of a populist argument is not its typically populist datum point or policy claim, but the type of warrant that it uses to connect a specific problem to a specific policy prescription. To illustrate, populist arguments typically follow that the identified problem (datum) constitutes a challenge to sovereignty and that as a general rule, populist governments must defend popular sovereignty, even if it requires radical or revolutionary foreign policy change. Why is sovereignty so central in populist arguments? According to Mudde's classic definition, populism claims that 'politics should be an expression of the volonté générale (general will) of the people' (Mudde 2004). Populists argue that elites or the establishment have made political institutions unresponsive to the general will of the people (Mair 2002; Hawkins and Kaltwasser 2019). The sovereignty warrant is therefore used to 'prove' the contention that revisionist foreign policy practices follow from a given data-point. The 'sovereignty' warrant- the principle that 'the people' should rule-lies at the heart of all populist arguments.

This explains why both right-wing and left-wing populists call for 'taking back control' from domestic and international elites (Kallis 2018). All populist discourses seem to make claims for enhancement or status elevation of the 'the people' (Basile and Mazzoleni 2020). Nationalism, too, relies on a sovereigntist warrant, but in this case the idealized sovereign is 'the nation.' While (ethno)nationalism invokes national sovereignty as a mean to support the interest of an (ethnic) national community against 'national others,' populism invokes popular sovereignty to support the political community against hostile economic and political elites. These threats are sometimes linked together in ethnonationalist-populism (hereafter, 'ethnopopulism'), wherein the idealized sovereign to be defended and elevated is the 'peoplenation' against threats from above as well as from beyond, such as globalist elites and refugees who might be working in concert to weaken the 'people-nation' (Jenne 2018, p. 546; see also De Cleen 2017; Brubaker 2020; Jenne 2021).

In sum, whether a drive for a new foreign policy comes from the top-down initiative of the leader or bottom-up demands of the citizens, an argument must be made to persuade the public of the value of radical foreign policy change. Sovereignty warrants serve as the justificatory bridge for enacting such policies. In our case analysis, we show that popular (sometimes articulated together with national) sovereignty warrants played a crucial role in all three components of populist foreign policy that justified and enabled systemic foreign policy revisionism in the Hungarian case (Jenne 2021).

\section{Post-2010 Hungary: a pathway case}

It is hard to imagine a case better suited to study the effects of populism on foreign policy than contemporary Hungary. Since 2010, Viktor Orbán, a veteran politician and self-styled populist, has governed the country with a veto-proof parliamentary supermajority. Not only has he made consistent use of populist rhetoric during that time, but he has faced few internal constraints on his foreign policy action. Although we study the case of Hungary primarily due to our country expertise, we believe it serves as a fruitful 'pathway case' to test theories 
about how populism influences foreign policy outputs and foreign policy processes. According to Gerring, a pathway case is one in which the outcome (Y) is well-predicted by the effect $(\mathrm{X})$; hence, the case may be explored to reveal the way in which the intervening causal mechanism produces the predicted outcome (Gerring 2007, see also Weller and Barnes 2014). On the input side (X), post2010 Orbán is widely acknowledged as a populist leader who has employed both populist and ethnonationalist rhetoric in his domestic and international speeches (Jenne et al. 2021; Csehi and Zgut 2021). On the output side (Y), there is little doubt that Orbán presided over radical reforms in Hungarian foreign policy, precisely in the ways outlined by the editors of this special issue (Palonen 2018; Liang 2016; Verbeek and Zaslove 2017; Szent-Iványi 2020; Varga and Buzogány 2020; Sata 2020). Because this case is well-predicted by expectations outlined in this special issue, it serves as a natural laboratory for assessing the causal mechanism.

The full story of Hungary's shift to populist governance goes beyond the scope of this brief article, but we summarize it shortly here. During Orban's first stint as prime minister in 1998-2002, Fidesz identified as a mainstream national conservative party. In the eight years in opposition, he transformed Fidesz into a catch-all people's party, combining his nationalistic rhetoric with a new populist discourse. The party's anti-communist heritage ensured that it would always have a primarily right-wing constituency, but after a failed referendum on offering Hungarian citizenship to co-ethnics in neighboring countries in 2004, Fidesz took a strategic turn away from national identity politics (Greskovits 2020). Its new discourse, centered around social issues, fears and insecurities of the common people meant that while Fidesz kept an exclusionary definition of the people as an ethnicity-based nation (Mudde and Kaltwasser 2013), in its rhetoric the populist element gained more and more importance over the nationalist aspects.

In the meantime, the ruling Socialist government suffered a progressive collapse in popular support. The governing coalition was rocked by a series of scandals, beginning in 2006 with leaked statements by the prime minister attesting to a closed party meeting that they had 'lied [to the Hungarian people] morning, evening and night,' sparking street riots and a harsh police crackdown. The 2008-10 global recession and sovereign debt crisis hit the country particularly hard, with the depreciation of the forint pushing a substantial proportion of Swiss franc-backed home mortgage-holders to the brink of default. The Fidesz Party, still headed by Orbán, capitalized on these failures by running a populist election campaign built around the promise of hope and change.

Orbán's 2010 election campaign now gave pride of place to populist elements alongside nationalism in his political addresses, with slogans such as 'Now is the time!' 'Change!' but little in the way of concrete policy proposals. Scoring a supermajority two-thirds control of the unicameral parliament, Orbán presented a populist vision of the total unification of the Hungarian people in the 'System of National Cooperation': 'Today there was a revolution in the polls,' and 'Hungarians have overthrown the system and created a new one. The old system of leaders misusing their power was replaced by one of national unity.' (CNN 2010). Since 2010, populism has been omnipresent in Orbán's public addresses. 
For sources of populist argumentation, we rely on Viktor Orbán's speeches on foreign policy. Between 2011 and 2016, the prime minister delivered speeches every year at the annual conference of Hungarian ambassadors on the general direction in Hungarian foreign policy. Second, we examined a number of essays and papers penned by key ideologists close to the prime minister, helping us to contextualize Hungarian foreign policy-making. Third, we examined the political speeches and statements about the key policy decisions and projects of international relevance, including Hungary's relations with the EU, Russia and China. Finally, we have collected campaign literature as well as periodic 'national consultation' questionnaires, which are plebiscitarian tools used by the government to demonstrate the popular legitimacy of its policy positions.

To assess the empirical fingerprints of populist arguments on Hungarian foreign policy, we track institutional changes in the foreign policy apparatus over the past decade - the Ministry of Foreign Affairs (MFA) and the Prime Minister's Office (PMO). To identify changes in the foreign policy apparatus, we examine organigrams of government institutions involved in foreign affairs at every point. In Hungary, changes in the structure of government institutions are codified in new or amended Organizational and Operational Rules (OORs), which publish updated organigrams of the ministries in 'Magyar Közlöny,' the official journal of the Hungarian government. With the help of legal databases, all changes in the OORs and organigrams of the MFA and PMO can be tracked. Systematically comparing the versions of the institutional OORs and organigrams gives us an indication of what units, departments and policy fields appeared or disappeared, expanded or shrank, became prioritized or marginalized within the foreign policy institutions over time.

\section{Empirical analysis}

The following section summarizes the results of our case study analysis in each of the three areas of foreign policy revisionism identified above. We first document the radical changes in Hungarian foreign policy, describing the institutional fingerprints of these foreign policy practices in the foreign policy apparatus. We then show how Orban and his allies used populist argumentation to justify these reforms to domestic and foreign publics and overcome salient counter-arguments.

\section{Politicization and personalization of foreign policy apparatus}

The first hallmark of populist foreign policy is the personalization and politicization of diplomacy. After Viktor Orbán returned to power in 2010, he wasted no time planting party loyalists to positions previously occupied by nonpartisan bureaucrats (Müller 2016: p. 44). He pushed through the modification of the Hungarian civil service law in his first month in office, making it possible to lay off civil servants without justification. Orbán initially staffed the MFA with seasoned diplomats, reappointing János Martonyi as foreign minister. Martonyi, a polyglot international lawyer known for his technocratic expertise and strong Atlanticist commitment, had 
been foreign minister during in the previous Fidesz government. Under Martonyi's leadership, the MFA invoked shared democratic values to justify its pro-Western stance (MFA 2011).

Following his second supermajority win in 2014, Orbán executed a deep structural transformation of the foreign policy apparatus. He first replaced Martonyi with Deputy Prime Minister Tibor Navracsics and then named the young and agile politician, Peter Szijjártó, the new foreign minister. Szijjártó had been Orbán's personal spokesperson, and at the PMO he had built up an independent international economic and trade affairs portfolio outside the reach of the MFA. Following Martonyi's dismissal, Szijjártó transferred his entire trade portfolio to the MFA, and within a few months was made minister. Once installed, Szijjártó rapidly restructured the ministry's foreign policy-making institutions. Orbán characterized these changes as 'a very serious break with the traditions of Hungarian foreign policy thinking and foreign policy management.' He later recount that he had used veteran diplomats to defend internationally contested government policies in the early years, 'leaving the structural transformation of the foreign affairs to the very end.' (Orbán 2016).

At the same time, Orbán strengthened the Prime Minister's Office (PMO) by assuming important foreign policy competences. The expansion of the PMO is not unique to Hungary; the 'presidentialization' of governance structures has occurred in a number of European democracies (Körösényi 2006; Tóth 2017). However, in Hungary it has been extremely far-reaching. The PMO was founded in 2011 as a simple organization that supported the PM's day-to-day work, including only 27 entities on its organigram. By 2019, that number had expanded to over 200 units - in addition to personal projects like stadium construction, the renovation of the Buda Castle, Hungarian film industry and 'patriotic and military education,' key foreign affairs portfolios were also moved there, including EU affairs. This has been described by analysts as a move toward a 'chancellor-type' governance, in which the Prime Minister's Office serves as a 'flagship institution' (Sárközy 2012; Stumpf 2016). Even after Mr Szijjártó was appointed as minister of foreign affairs, many foreign policy areas remained at the PMO under Orbán's close supervision. ${ }^{2}$

The sheer number of changes introduced to the structures and competencies of the MFA and the PMO in the years following the paradigm shift dwarfs any other period of institutional change in Hungary since the end of the Cold War. Over nine years, we identified 35 different versions of the OOR for the PMO and 21 different versions for the MFA. The PMO experienced even higher institutional volatility in the following three years. Figure 2 shows how institutional changes were rather unevenly distributed, and how they peaked during Orbán second term of office, in 2014-2017.

\footnotetext{
${ }^{2}$ An important exception is EU affairs, which was also carved out of the PMO structure, but later moved to the Ministry of Justice. Orbán appointed his state secretary of EU affairs, Judit Varga, the new minister of justice. Similar to Péter Szijjártó, Ms Varga was also allowed to keep her original portfolio when moving to the Ministry of Justice.
} 


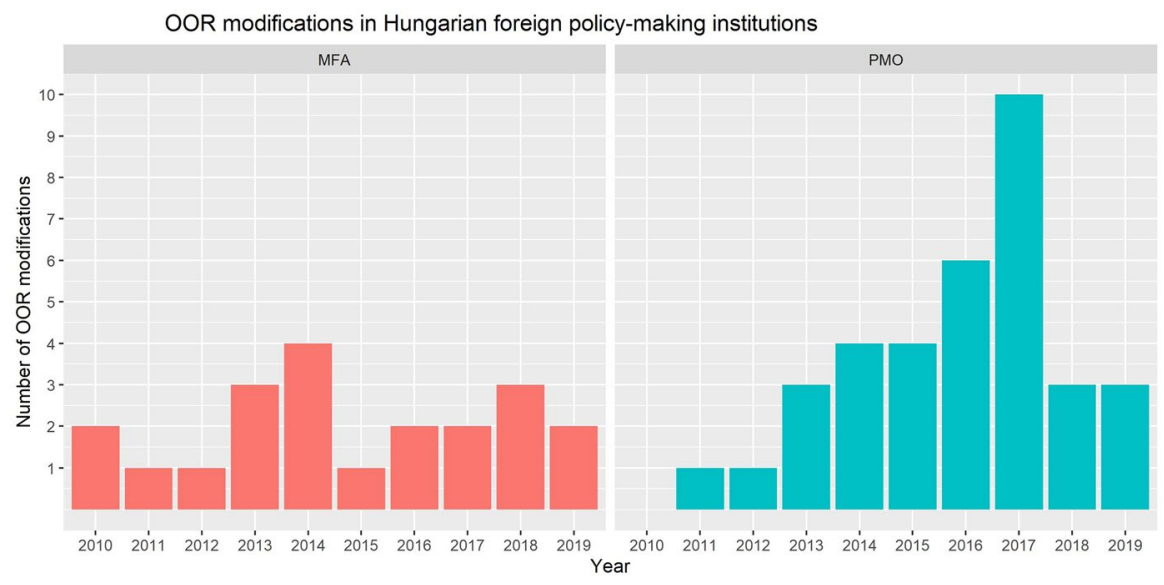

Fig. 2 OOR modifications in Hungarian foreign policy-making institutions

There were also massive personnel changes within the Hungarian diplomatic service. Media reports in the summer of 2014 called the handover an 'invasion, system change, or clear-cutting,' reporting more than 200 new ID cards issued for new staff at the Foreign Ministry, which had roughly 600 employees overall-a huge rotation (Népszabadság 2014). Other newspapers reported that on the day before Szijjártó took office, the entire ministerial cabinet and communications team was fired in a single stroke (HVG 2014a). After Szijjártó's arrival, all state secretaries were replaced; shortly thereafter, the ministry announced that 107 people would be fired from the ministry by the end of the month (HVG 2014b). In Szijjártó's first month in office, 34 ambassadors were removed, with many more to follow (Dezső 2014). According to media reports, employees felt that the new leadership did not trust the staff who worked previously under Martonyi's leadership; new hires were told not to mingle or talk to old employees.

\section{Arguments supporting the politicization of the foreign policy apparatus}

Arguments for these changes can be found in two bodies of texts: (1) the works of key ideologists who wrote about the foreign policy apparatus, and (2), speeches by Orbán himself at the annual conferences of Hungarian ambassadors. The populist argumentation typical of Orbán in the early 2010s was strongly conditioned by the 2008-10 global financial crisis, which left the country at the mercy of IMF conditionality. Departing from the datum of looming sovereign default, he claimed that Hungary needed to 'launch a new foreign policy doctrine and way of thinking,' an 'independent foreign policy' that is 'measured by the prosperity of the Hungarian people' (Orbán 2015). He used a sovereignty warrant to connect the datum to the claim: 'serious money owners and investors' (elites) threatened Hungarian sovereignty (the people) because they were 'interested in keeping countries permanently on the edge of bankruptcy' (Orbán 2011). Contradicting Martonyi’s accommodationist approach, Orbán argued that Hungary could either be 'sovereign' and 
successful or accept 'subordination' and 'vassalhood.' In the ontological struggle for sovereignty, there was no place for 'experts' like the diplomatic old guardit required politically loyal lieutenants committed to serving the people and their leader.

Key ideologists prepared the ground for a politicized foreign policy by promulgating the principle of 'political governance.' In a 2008 paper, István Stumpf and Gábor G. Fodor, leading political analysts of the pro-Fidesz think-tank Századvég Foundation $^{3}$ argued that the state had to be rescued from the neoliberal discourse of 'political hedonists'; 'bureaucracy had to be put to the service of political power' (G. Fodor and Stumpf 2008, quoted in Mándi 2015, 28). Handling problems of a political nature is a task for politicians-political crises cannot be resolved by intellectuals, economists or other experts (Mándi 2015, 28). Political governance implies that diplomacy (and bureaucracy in general) must be under direct control of the political leader who represents the people's will; there was no place in the diplomatic apparatus for technocrats who act upon abstract values unconnected to the will of the people.

Orbán extended his argument for a political foreign policy in his ambassadorial speeches, complaining about the 'technocratic illusion' of previous leaders who believed 'it was better to place technocratic experts at the helm of the countries rather than elected political leaders.' Because unelected technocrats had no legitimacy, their decisions would not be accepted by the people, creating a legitimacy crisis (Orbán 2012). Orbán repeatedly stressed the importance of political loyalty in his speeches to Hungarian ambassadors, telling them that 'good results can only be achieved with disciplined soldiers.' (Orbán 2012) Hungarian diplomats 'cannot be world citizens'; they must see the world from the Hungarian perspective, otherwise they are not qualified to represent Hungarian national interests. (Orbán 2015).

Orbán's populist argument for the politicization of foreign policy-making can be graphed as follows:

- Datum: Financial speculators have imperiled the Hungarian economy.

- Populist Warrant: Financial dependence on outside actors threatens the interests of the people.

- Claim: Hungary can overcome the crisis by replacing career diplomats with political appointees who prioritize the interests of the people.

Counter-arguments to the politicization of the MFA came mostly from former diplomats and analysts who argued that it is actually technocratic expertise that enables diplomats to serve the people's interests. One fired ambassador reportedly described the mass discharge of senior staff as 'the massacring of elite teams,' by which the MFA lost thousands of contacts with foreign diplomats, harming the reputation of the country abroad (Dezső 2014). Another fired ambassador recounted that

\footnotetext{
3 István Stumpf was the head of Orbán's Prime Minister's Office during the first Orbán government in 1998-2002 and was the director of Századvég Foundation from 2002. Gábor G. Fodor joined Századvég as a political analyst, and eventually rose to the position of strategic director in the think tank.
} 
the ministry had been restructured with 'uneducated, arrogant zest' that dismissed diplomatic expertise (Ruzsbaczky 2015). Szijjártó easily rebutted these counterarguments by reducing Orbán's critics to subjects in his sovereignty warrant. The critics were recast as 'Brussels elites'-products of 'deep-rooted structures,' who must be rooted out 'in the interests of Hungary.' Thus diminished, their concerns were easily brushed aside in the interests of elevating Hungary 'in the new world order' (Mandiner 2014).

\section{Confrontation with traditional allies}

The second hallmark of populist foreign policy is a style of confrontational diplomacy toward the perceived power-holders in the system in order to free the country from alliance commitments that are seen as holding the country back. While the previous Socialist governments pursued consensus-seeking strategies toward the EU based on the assumption of shared interests, from the early 2010s, the Orbán regime consciously chose to enter high-level diplomatic conflicts with its Western allies. Orbán proudly 'sent home' the IMF after it had helped to bail out the country during the economic crisis, initiated a conflict with the UN over its migration package, and began to use its veto powers in the EU and in NATO. After Russia annexed Crimea, Hungary used its veto powers in NATO to block high-level NATOUkraine meetings and joint military exercises (Panyi 2020). Budapest also began to veto joint EU resolutions or decisions seen as harmful to its new eastern alliesChina, Russia and Turkey (Magyari 2018; Panyi 2019; Becker 2019). Together with Poland, Hungary threatened to veto the entire seven-year budget of the EU to block an unwanted rule of law mechanism. Finally, it has vetoed a number of joint EU declarations and international agreements deemed too 'pro-migrant.' In sum, Orbán went from a position of solid trans-Atlanticism and EU integration to a vocal stance of suspicion and hostility toward multilateral organizations like the EU and the UN, selectively activating Hungary's veto rights to back up his confrontational foreign policy practices.

Orbán's confrontation with Hungary's allies is limited by the fact that it is a small, landlocked European country with no real economic or military power. Furthermore, the country is a net beneficiary of both EU development funds and the security offered by NATO, so leaving either of these organizations would cost Orbán dearly. Conflictual behavior in this case should therefore be understood as an attempt to use and increase Orbán's room for political maneuver, not as the indication of his intention to break away. In this, he has relied heavily on legalese and technical arguments in his self-described 'pávatánc' ('peacock dance') that he performs for international audiences. The organizational frameworks of NATO and the EU offer their member states the legal instruments for confrontation that are otherwise unavailable to small states on the international stage. It is only through these organizations that Orbán can, for example, obstruct German aspirations in the EU or US aspirations in NATO.

Hungary's newly confrontational stance has left institutional fingerprints. The Prime Minister's Office has devoted significant resources to international 
communication to fight the government's discursive battles in the international arena. In a bid to communicate his arguments to foreign audiences, Orbán established a new Cabinet Office for the Prime Minister, which gained the status of a ministry-supplying Orbán with an additional press office, communication department, information office, foreign affairs department and program-organizing department. The Cabinet Office expanded further in 2018 with an International Communications Office and an international spokesperson at the rank of state secretary tasked with managing the regime's image abroad.

As if in tandem, reforms undertaken at the MFA indicated a diminished interest in multilateralism. The departments dealing with the UN and OSCE were first lumped together under 'global affairs' (2010-2013), then 'security policies' (2014), and still later 'international cooperation' (2014-2017). When the government began to challenge the UN's planned migration pact (Euronews 2018), the departments responsible for the UN and other international organizations were removed from aid and humanitarian affairs altogether and placed under a rebranded deputy state secretary for 'Handling the Challenges of Migration.' this move suggests that the Hungarian government now sought to engage the UN and other IOs principally under the banner of anti-immigration policies, invoking an ethnopopulist sovereign warrant calling for protection of 'the people' as an ethnocultural unit or 'nation.'

\section{Arguments supporting confrontation with traditional allies}

The political arguments for confrontational diplomacy can be found in Orbán's ambassadorial speeches, in which he encouraged Hungarian diplomats to resist EU pressures that conflict with sovereign interests. In his speeches, Orbán repeatedly enjoined diplomats to take a tougher line toward the EU. The diplomatic corps was to resist all attempts by the EU to regulate national competencies, which Orbán characterized as an attack on national sovereignty. In the wake of the 2015 refugee crisis, he insisted that ambassadors marshal a fierce resistance against the imposition of refugee quotas. He disparaged the 'certain culture in Hungarian diplomacy' that avoids conflict, proclaiming that 'Hungary stands firmly for its national interests, and this comes with conflict.' (Orbán 2013).

Orbán communicated this argument to the Hungarian public through a series of 'national consultations' that solicited public opinion on the government's marquee positions. The 2015 National Consultation on immigration began with the datum of Brussel's incompetence, stating that 'as Brussels failed in handling immigration, Hungary has to walk its own way.' (Hungarian Government 2015) In 2017, a National Consultation labeled 'Stop Soros' swapped George Soros in for Brussels, drawing on antisemitic tropes of powerful Jews conspiring to destroy nations: 'In line with George Soros' proposal, an EU-level Asylum and Migration Agency will be established that will further weaken national competencies in the area of immigration. If immigration quotas come into force, Hungarians will no longer have a say in who they want to live with.' (Hungarian Government 2017). The 2020 National Consultation on the Coronavirus also contained a claim that Brussels continued to 'plan its attack' on the Hungarian Constitution and that the government should fight 
de-racination of the country 'even at the price of open conflict with Brussels.' (Hungarian Government 2020).

Graphing this argument, we plainly see the following structure. The claim for confronting the EU based on the datum that 'Brussels' is usurped the powers that rightfully belong to the national sovereign through 'sneaky federative policies,' which attempted to build a 'bureaucratic empire' (Orbán 2013). The datum built to the conclusion that Hungary should implement its own unique solutions instead of the proposed common policy. The two were connected, in this particular case, by an ethnopopulist sovereignty warrant that when the ethnocultural nation is threatened by elites and national others, and these 'plans' must be defeated.

- Datum: The EU and UN want to force Hungary to accept refugees from the Middle East and North Africa.

- Ethnopopulist Warrant: Sovereign nations have the right to pursue their own interests without external infringements by global elites and national others.

- Claim: Hungary must adopt national-level immigration policies rather than accept EU-level solutions.

Rebuttals to this claim can be found in the minutes of debates on the parliamentary floor, where opposition MPs have had the opportunity to question Fidesz policies. The main counter-argument was that bellicose diplomacy was harmful to Hungarian interests because it damaged its relations with valued Western allies. For example, following a series of diplomatic dust-ups with other EU countries and the US, ${ }^{4}$ opposition MPs argued that Szijjártó's outbursts 'swept aside the basic principles of diplomacy' (Demeter 2014), which contributed to the weakening of the EU, hence serving Russian rather than Hungarian interests (Szakács 2014). The government's counter-rebuttal has been to discredit their critics as 'Soros emberei' (Soros agents) who were part of the Soros plan and hence colluding with globalist elites and Brussels.

\section{Solicitation of non-traditional partnerships}

The third hallmark of populist foreign policy is the diversification of partnerships through the pursuit of non-traditional allies. In 2014, the government launched a radically new foreign policy strategy called 'Keleti Nyitás' ('Eastern Opening'). The strategy was later amended with a plan for 'Déli Nyitás' ('Southern Opening') to diversify Hungarian trade relations. The goal was to increase Hungarian exports to,

\footnotetext{
${ }^{4}$ In the fall of 2014, Szijjártó made a series of strong statements against European and American leaders criticizing the Hungarian government, among others proclaiming that the Swedish Minister of European Affairs is spreading lies about Hungary and the Hungarian people, and the Norwegian Minister of European Affairs is making statements that lack credibility and disregards basic facts, and arguing that the US president is misinformed about Hungary.
} 
and foreign direct investment from, non-EU countries to reduce Hungarian dependence on EU markets. ${ }^{5}$

The pursuit of bilateral deals beyond Europe and North America is not a completely new idea. In 2011, Martonyi launched a policy of 'Globális Nyitás' ('Global Opening'), which envisioned partnerships outside the EU. However, whereas the 'Global Opening' called for multilateral engagement on terrorism, global food and health programs 'to strengthen Hungary's international position' (MFA 2011:36-37), Szijjártó's 'Eastern Opening' advocated advancing Hungary's economic interests through bilateral political and trade relations with Asian and Middle Eastern partners. Hungary has forged lasting ties with its non-traditional partners through the Russia-financed Paks nuclear power plant, the reconstruction of a Chinese-financed Budapest-Belgrade railway line, and most recently, with the planned establishment of a Chinese Fudan University in Budapest.

The 'Eastern Opening' has left clear institutional fingerprints on the foreign policy machinery. As of 2012, the PMO, which previously had no departments dealing with trade or the economy, introduced a State Secretariat of Foreign Affairs and Trade, which included a deputy state secretary and two general departments for trade and foreign affairs and a third for 'multilateral and bilateral negotiations.' Once Szijjártó was appointed as foreign minister, the MFA was renamed the Ministry of Foreign Affairs and Trade (MFAT), suggesting a shift toward a neo-mercantilist foreign policy. After 2014, Russia and China each had their own dedicated general departments in the MFAT. The new organization created three deputy state secretariats: one for the new allies under 'Eastern Opening,' one for traditional allies ('European and American relations'), and a third for 'economic diplomacy.' By 2019, the deputy state secretariat for Western allies was just one unit out of the six under the deputy minister; the other five were dedicated to non-traditional allies or economic issues.

\section{Arguments for pursuing non-traditional partnerships}

The government's arguments for foreign policy diversification start from the datum of perceived global power shifts. Hungary's 2011 strategy document forecast a period of 'multipolarization,' when the leading role of the US and Europe would gradually decline. (MFA 2011:5). In successive ambassadorial speeches, Orbán declared that Hungary must adapt to this 'new world order' to 'gain an advantage relative to others' (Orbán 2015). In his speeches, he declared that diplomacy was actually a 'race of nations' (Orbán 2011, 2016), in which partnership diversification yielded greater payoffs than the 'bloc mentality' endemic in the Hungarian diplomatic corps.

To make these claims plausible, Orbán invoked a mostly national sovereignty warrant that free nations must be free to do business with non-traditional partners,

\footnotetext{
${ }^{5}$ Hungary is a heavily export-dependent country, with over $80 \%$ of its GDP coming from exports. In 2014, Viktor Orbán set a goal to reduce the proportion of Hungarian exports to EU countries from 80 to $50 \%$, while increasing Hungarian exports to non-EU countries. The argument Orbán used was that 'in a fundamentally export-oriented country foreign policy also has to be economy-centered' (Orbán 2014a).
} 
regardless of their ideological character, as well as a populist warrant to that the Hungarian government must reject the dictates of the Western establishment. In an early address, he averred, 'It is not similarity to Western strategies that makes Hungarian foreign policy good. Hungarian foreign policy is good if it serves the national interest, which has to be defined in each context' (Orbán 2012). In this nationalistpopulist argument, dual sovereignty warrants were used to reject Western imperial dictates that Hungary remain in the western liberal bloc to a foreign policy that prioritized Hungarian national interests without regard to ideology. Emphasizing Hungary's sovereign right to manage its affairs as it pleases, Orbán argued that Hungary's non-traditional partnerships should not meddle in the partners' internal affairs, but should be based on pragmatic cooperation that serves the people's interest. In other words, Hungary should not abandon the West, but rather expand beyond the Western bloc to secure economically beneficial partnerships: 'although we sail under Western flags, an Eastern wind blows in the global economy' (Orbán 2010, quoted in Rácz 2019). ${ }^{6}$

Graphing Orbán's nationalist-populist argument for the diversification of partnerships produces the following structure:

- Datum: The West is in decline, and the East is on the rise.

- (Nationalist-Populist) Warrant: Sovereign nations have every right to do business with anyone as long as it serves their interests, regardless of the dictates of power-holders.

- Claim: Hungary needs to build new alliances, intensify its partnership with Russia, China, the Arab world.

Counter-arguments for the turn toward non-traditional partners can be identified in the statements of opposition party MPs and analysts who marshaled evidence showing that the Russian nuclear plant was expected to produce massive deficits (Candole Partners 2016), the Chinese railway did not promise significant economic returns, and the export gains from other new partnerships underperformed expectations (Kovács 2019). Others argued that economic ties with Eastern autocrats also meant political dependency and hence the loss of sovereignty (Szelényi 2014, Tóth 2014). The government rebutted these arguments by doubling down on expectations of economic benefits, while pointing out that Western critics are guilty of 'double standards’ given their own close relations with Russia and China. (Lázár 2014).

\footnotetext{
6 This sovereignty-based argument of mutual respect and non-interference is not only used in the characterization of partnership with Eastern autocracies, but also dominates debates where Hungary is criticized for its democratic backsliding. In such debates, Orbán often demands respect and non-interference from Western partners in the name of sovereignty. Interestingly, though, such argumentation does not hold Orbán back from actively interfering in other states' politics, by actively campaigning for his allies Ukraine, Romania, Serbia or Slovenia, or his cronies from building up influential media empires in the Western Balkans that support Orbán's political allies.
} 


\section{Conclusion}

We have argued that Hungarian foreign policy under Viktor Orbán from 2010 to 2020 is a 'pathway case' of populist foreign policy. In under a decade, Hungary had abandoned its Western technocratic foreign policy approach as a reliable EU and NATO partner in favor of personalized foreign policy apparatus that sought re-engagement with the once-feared Russia and a new partnership with China. With the help of a modified Toulmin model, we show the role of populist, ethnopoulist and nationalist-populist sovereignty warrants by the Hungarian government in legitimizing each of these shifts toward foreign policy revisionism.

We have also shown that in the case of Hungary, populist rhetoric was not 'cheap talk' used by endangered leaders to distract from their leadership failures, because they actively used popular and national sovereignty warrants to justify concrete diplomatic action. It also left institutional fingerprints in the institutional structures of Hungarian foreign policy-making that together amount to confirmation of the role of argumentation in populist foreign policy. At the same time we find no support for a naïve 'costly signals' mechanism of policy intent, because the Fidesz constituency in 2010 was adamantly pro-EU and pro-NATO and suspicious toward Russia and China. However, after years of populist argumentation advocating for reorientation with the support of the sovereignty warrant, popular attitudes changed. The government's political rhetoric seem to have overwritten historical aversions about Russia and China, with opinion polls indicating that the population's sympathy toward these countries increased significantly during Fidesz's years in power (Krekó 2019).

We should note, however, that this strong role of the top-down supply of populist argumentation seemed to work in concert with strong bottom-up populist attitudes that make the population (or at least part of it) susceptible to sovereigntist warrants. While in terms of concrete foreign policy preferences, trust in Western institutions and suspicion toward the Eastern powers were dominant among Hungarian voters, their strong acceptance of sovereigntist warrants made them influenceable by populist arguments. According to ISSP surveys conducted in Hungary in 2003 and 2013, those agreeing that 'Hungary should follow its own interests, even if this leads to conflicts with other nations,' make up a stable 50 percent of the population, while those agreeing that 'International organizations are taking away too much power from the Hungarian government' increased from 44 to 50 percent. What this means is that populist argumentative may be a 'costly signal,' but one with the intent to undertake foreign policy revisionism rather than merely translating prior constituent preferences into policy.

Our arguments are in line with theories of populist foreign policy that emphasize the importance the political sovereignty claim (Verbeek and Zaslove 2015), and the relevance of globalization, regional integration, migration and finance in the agenda of populist foreign policy (Verbeek and Zasolove 2017). Our findings also resonate well with other case studies presented in this special issue about the foreign policy of populist regimes in Italy or Greece. Author A Chryssogelos shows that Greece under the populist Syriza-Anel coalition demonstrated a 
similar interest in moving away from its traditional allies, the EU and NATO, and form stronger ties with new allies such as Russia and China (Chryssogelos 2021 , in this special issue). In the same way, Coticchia shows how the Italian populist coalition, the Five Star Movement and the Northern League had a conflictual relationship with allies, and expressed strong interest in non-traditional partnerships (Coticchia 2021, in this special issue). However, neither government was in power long enough to undertake the kind of structural transformation and politicization of the diplomatic corps that Orbán was able to achieve during his second consecutive term in power with a supermajority of MPs in a unicameral parliament. Hence, the case of post-2010 Hungary stands not only as a "pathway case,' but also a paradigmatic case in which the populist leader achieved something close to the populist promise of fundamental systemic change.

Supplementary Information The online version contains supplementary material available at https://doi. org/10.1057/s41295-021-00256-3.

Acknowledgements Peter Visnovitz would like to thank the Reverend Dr. Tamás Gáncs of the Budapest Kelenföld Lutheran Church for offering shelter and working space during the Covid-19 office lockdowns, making the completion of this article possible. The authors gratefully acknowledge the research support provided by an Intellectual Themes Initiative grant from Central European University on which this paper is partly based.

\section{References}

Acemoglu, Daron, Georgy, Egorov, and Konstantin Sonin. 2013. A political theory of populism. MIT Department of Economics Working Paper No. 11-21.

András, Hettyey. 2021. The illusion of autonomy and new others: role conflict and Hungarian foreign policy after 2010. Journal of International Relations and Developmenthttps://doi.org/10.1057/ s41268-021-00228-w

Cadier, David. 2021. Populism, Politics of Representation and Foreign Policy change: Evidence from Poland, Forthcoming in this special issue.

Chryssogelos, Angelos. 2021. The dog that barked but didn't bite: Greek foreign policy under the populist coalition of SYRIZA-independent greeks, 2015-19. Forthcoming in this special issue.

Coticchia, Fabrizio. 2021. A sovereignist revolution? Italy's foreign policy under the "Yellow-Green" government. Forthcoming in this special issue.

Destradi, Sandra, Cadier, David, Plagemann, Johannes. 2021. Populism and foreign policy change: A research agenda. Forthcoming in this special issue

Balfour, R., J.A. Emmanouilidis, H. Grabbe, T. Lochocki, C. Mudde, J. Schmidt, C. Fieschi, C. Hill, M. Mendras, M.K. Niemi, and C. Stratulat. 2016. Europe's troublemakers: The populist challenge to foreign policy. Brussels: European Policy Centre.

Basile, Linda, and Oscar Mazzoleni. 2020. Sovereignist wine in populist bottles? An introduction. European Politics and Society 21 (2): 151-162.

Billig, Michael. 1989. Arguing and thinking-A rhetorical approach to social psychology. Cambridge: Cambridge University Press.

Brubaker, Rogers. 2017. Between nationalism and civilizationism: The European populist moment in comparative perspective. Ethnic \& Racial Studies 40 (8): 1191-1226.

Brubaker, Rogers. 2020. Populism and nationalism. Nations and Nationalism 26 (1): 44-66.

De Cleen, Benjamin. 2017. Populism and nationalism. In The Oxford Handbook of Populism, ed. Cristóbal Rovira Kaltwasser, Paul Taggart, Paulina Ochoa Espejo and Pierre Ostiguy. Oxford: Oxford University Press.

De Cleen, Benjamin, and Yannis Stavrakakis. 2017. Distinctions and articulations: A discourse theoretical framework for the study of populism and nationalism. Javnost-The Public 24 (4): 301-319. 
Cobb, Michael D., and James H. Kuklinski. 1997. Changing minds: political Arguments and political persuasion. American Journal of Political Science 41 (1): 88-121.

Drezner, Daniel. 2017. The ideas industry-How pessimists, partisans, and plutocrats are transforming the marketplace of ideas. Oxford: Oxford University Press.

Enyedi, Zsolt. 2016. Paternalist populism and illiberal elitism in Central Europe. Journal of Political Ideologies 21 (1): 9-25.

G. Fodor, Gábor, Stumpf, István. 2008. Neoweberi Állam És Jó Kormányzás. [Neoweberian State and Good Governance], Nemzeti Érdek [National Interest] (3).

Freeden, M. 2017. After the Brexit referendum: Revisiting populism as an ideology. Journal of Political Ideologies 22 (1): 1-11.

Gerring, J. 2007. Is there a (viable) crucial-case method? Comparative Political Studies 40: 231-253.

Goddard, Stacie E., and Ronald R. Krebs. 2015. Rhetoric, legitimation, and grand strategy. Security Studies 24 (1): 5-36.

Greskovits, Béla. 2020. Rebuilding the Hungarian right through conquering civil society: The Civic Circles Movement. East European Politics 36 (2): 247-266.

Hawkins, Kirk, Ryan Carlin, and Levente Littvay. 2019. The Ideational Approach to Populism. London: Routledge.

Hawkins, K.A., and C.R. Kaltwasser. 2018. Introduction: The ideational approach. In The ideational approach to populism, 1-24. London: Routledge.

Homer-Dixon, Thomas, and Roger Karapin. 1989. Graphical argument analysis: A new approach to understanding arguments applied to a debate about the window of vulnerability. International Studies Quarterly 33 (4): 389-410.

Jenne, Erin. 2018. Is nationalism or ethnopopulism on the rise today? Ethnopolitics 17 (5): 546-552.

Jenne, Erin. 2021. Populism, nationalism and revisionist foreign policy. International Affairs 97 (2): 323-343.

Jenne, Erin K., Hawkins, Kirk A., Castanho Silva, Bruno. 2020. Mapping Populism and Nationalism in Leader Rhetoric Across North America and Europe, Studies in Comparative International Development 56(2): 1-27.

Kallis, Aristotle. 2018. Populism, sovereigntism, and the unlikely re-emergence of the territorial nationstate. Fudan Journal of the Humanities and Social Sciences 11 (3): 285-302.

Khong, Y.F. 1992. Analogies at war: Korea, Munich, Dien Bien Phu, and the Vietnam decisions of 1965. Princeton: Princeton University Press.

Klotz, Audie. 1995. Norms in international relations-The struggle against apartheid. New York: Cornell University Press.

Kornprobst, Markus. 2009. International relations as rhetorical discipline: Toward (re-)newing horizon. International Studies Review 11 (1): 87-108.

Körösényi, András. 2006. Gyurcsány-vezér. A magyar politikai prezidencializálódása. [Gyurcsány the leader. The Presidentialization of Hungarian Politics]. In Magyarország Politikai Évkönyve 2005rôl. [Hungary's Political Annals from 2005], ed. Péter, Sándor et al 141-149. Budapest: DKMKA.

Krebs, R. 2015. Narrative and the making of US national security. Cambridge: Cambridge University Press.

Krekó, Péter (2019) Russia in Hungarian public opinion. In Hungarian Social Report 2019, ed. Tóth, István György, pp. 358-371.Tárki Társadalomkutatási Intézet Zrt.

Levitsky, Stephen, and Kenneth M. Roberts. 2011. The resurgence of the Latin American left. Baltimore: Johns Hopkins University Press.

Liang, Christina Schori. 2016. Europe for the Europeans-The foreign and security policy of the populist radical right. London: Routledge.

Mair, P. 2002. Populist democracy vs party democracy. In Democracies and the populist challenge, 81-98. London: Palgrave Macmillan.

Mándi, Tibor 2015. Politikai Gondolkodás. [Political Thought]. In A Magyar Politikai RendszerNegyedszázad Után [The Hungarian Political System-After a Quarter of a Century], ed. András Körösényi, 13-34. Budapest: OSIRIS - MTA PTI.

Mudde, Cas. 2004. The populist zeitgeist. Government and Opposition 39 (4): 541-563.

Mudde, Cas. 2017. An ideational approach. In The Oxford Handbook of Populism, ed. Rovira Kaltwasser Taggart and Ochoa Espejo Ostiguy. Oxford: Oxford University Press.

Mudde, Cas, and Cristobal Rovira Kaltwasser. 2013. Exclusionary vs. inclusionary populism: Comparing contemporary Europe and Latin America. Government and opposition 48 (2): 147-174. 
Mudde, Cas, and Rovira KaltwasserCristobal. 2012. Populism in Europe and the Americas-Threat or corrective for democracy? Cambridge: Cambridge University Press.

Müller, Jan-Werner. 2016. What is populism? Philadelphia: University of Pennsylvania Press.

Palonen, Emilia. 2018. Performing the nation: The Janus-faced populist foundations of illiberalism in Hungary. Journal of Contemporary European Studies 26 (3): 308-321.

Paris, Roland. 2002. Kosovo and the metaphor war. Political Science Quarterly 117 (3): 423-450.

Plagemann, Johannes, and Sandra Destradi. 2019. Populism and foreign policy: The case of India. Foreign Policy Analysis 15 (2): 283-301.

Robert, Csehi, Edit, Zgut. 2021. 'We won't let Brussels dictate us': Eurosceptic populism in Hungary and Poland. European Politics and Society 22(1) 53-68 https://doi.org/10.1080/23745118.2020.1717064

Roberts, Kenneth M. 1995. Neoliberalism and the transformation of populism in Latin America. World Politics 48 (1): 82-116.

Rodrik, Dani. 2018. Populism and the economics of globalization. Journal of International Business Policy 1: $12-33$.

Sárközy, Tamás. 2012. Magyarország Kormányzása, 1978-2012: A Szoft Diktatúra Kormányzásától Az Újkapitalista Konfliktusos Demokrácia Kormányzásán Át a Fülkeforradalom Vezérdemokráciájának Kormányzásáig. [The Governance of Hungary, 1978-2012: From Soft Dictatorship Governance to Neo-Capitalist Conflict Democracy Governance to the Leader Democracy Governance of the Polling Booth Revolution], Park Könyvkiadó.

Sata, Robert, and Ireneusz Pawel Karolewski. 2020. Caesarean politics in Hungary and Poland. East European Politics 36 (2): 206-225.

Snyder, Jack. 2000. From voting to violence: Democratization and nationalist conflict. New York: Norton.

Stumpf, István. 2016. Reinventing government and the separation of powers. Hungarian Journal of Legal Studies 57 (1): 42-58.

Subotić, Jelena. 2016. Narrative, ontological security, and foreign policy change. Foreign Policy Analysis 12 (4): 610-627.

Szent-Iványi, István. 2020. Quo vadis Hungaria? [Where Is Hungary Heading?]: Foreign Policy Dilemmas and Strategic Vision. Republikon Intézet.

Taggart, Paul A. 2000. Populism. Buckingham: Open University Press.

Thies, Cameron G. 2012. International socialization processes vs. Israeli national role conceptions: Can role theory integrate IR theory and foreign policy analysis? Foreign Policy Analysis 8: 25-46.

Tóth, László. 2017. 'A végrehajtó hatalom prezidencializálódásának egyes aspektusai a II. és III. Orbánkormányok esetében' [Some aspects of the presidentialization of the executive power in the case of the 2nd and 3rd Orbán governments]. Parlamenti Szemle 2: 47-68.

Toulmin, S. 1958. The uses of argument. Cambridge: Cambridge University Press.

Toulmin, S., R. Rieke, and A. Janik. 1984. An introduction to reasoning. New York: MacMillan.

Varga, Mihai, and Áron. Buzogány. 2020. The foreign policy of populists in power: Contesting liberalism in Poland and Hungary. Geopolitics 2020: 1-22.

Verbeek, Bertjan, and Andrej Zaslove. 2015. The counter forces of European integration: Nationalism, populism and EU foreign policy. In The SAGE handbook of european foreign policy. Thousand Oaks: SAGE.

Verbeek, Bertjan, and Andrej Zaslove. 2017. Populism and foreign policy. In The Oxford Handbook of Populism, 384-405. Oxford: Oxford University Press.

Weller, Nicholas, and Jeb Barnes. 2016. Pathway analysis and the search for causal mechanisms. Sociological Methods and Research 45 (3): 424-457.

Weyland, Kurt. 2001. Clarifying a contested concept: Populism in the study of Latin American politics. Comparative Politics 34 (1): 1-22.

Wojczewski, Thorsten. 2020. Enemies of the peopl': Populism and the politics of (in) security. European Journal of International Security 5 (1): 5-24.

Zellman, Ariel. 2020. Cheap talk or policy lock? Nationalist frames and sympathetic audience cost in international territorial disputes. Territory, Politics, Governance 8 (3): 336-355.

Publisher's Note Springer Nature remains neutral with regard to jurisdictional claims in published maps and institutional affiliations. 
Peter Visnovitz is a doctoral candidate at Central European University's PhD Program in Political Science. His research focuses on populist legitimacy in opposition and power, tracking how populist actors construct representative roles and group identities, and how these relate to policies pursued by populists in government. He participated in various research projects at Yale, Princeton, and the Hungarian Center for Social Sciences, and he teaches populism theory at Eötvös Loránt University, Budapest.

Erin Jenne is a Professor at the International Relations Department at Central European University, where she teaches courses on foreign policy analysis; nationalism, populism and ethnic conflict management; and mixed methods and research design. She has received numerous grants and fellowships, including a MacArthur fellowship, Carnegie Corporation scholarship, a Senior Fernand Braudel fellowship at European University Institute (EUI), and a Minerva Grant from the US Office of Naval Research. Her first book, The Paradox of Minority Empowerment (Cornell University Press, 2007) is the winner of Mershon Center's Edgar S. Furniss Book Award. Her work has appeared in numerous journals, including International Affairs, International Studies Quarterly, Security Studies, Regional and Federal Studies, Journal of Peace Research, Civil Wars, International Studies Review, Research and Politics and Ethnopolitics. 